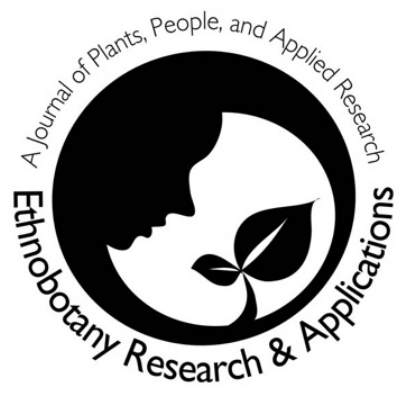

\title{
Cultural importance of wild edible plants in three sympatric communities: Agni, Akyé and Gwa in the Department of Alépé (Southeast of Côte d'Ivoire)
}

Amadou Lamine Diop, Djah Fançois Malan, Yao Bertin Kouakou, Amani Léopold Litta, Kouassi Gérard Kouassi

\section{Correspondence}

Amadou Lamine Diop*, Djah François Malan, Yao Bertin Kouakou, Amani Léopold Litta, Kouassi Gérard Kouassi

UFR Sciences de la Nature, NANGUI ABROGOUA University, PO. Box 801 Abidjan 02, Abidjan, Republic of Côte d'Ivoire

*Corresponding Author: amadoulamine08@gmail.com

Ethnobotany Research \& Applications 22:35 (2021)

\section{Research}

\begin{abstract}
Background: Wild plants are plants that are neither cultivated nor domesticated by humans. This study aimed to assess the knowledge level about wild edible plants used in the communities living in the same area.

Methods: An ethnobotanical survey was carried out in ten different villages which are parts of three studied communities. Two sets of surveys were used. The first type was a house-to-house based survey on free lists interviews. The second type of survey was a walk-in-the woods with some key informants identified by the communities. Frequency of quotation, Smith's index and cultural importance index were used to estimate the knowledge level of the communities. Venn diagram, Jaccard similarity index and the hierarchical clustering were used to compare the distribution of the knowledge in the communities. Whereas the Kruskal-Wallis test and the Mann-Whitney test were used to assess the significance of difference in plants used by the communities.
\end{abstract}

Results: Through the studied communities, 43 wild edible plants were collected. Myrianthus arboreus, Dacryodes Klaineana, Elaeis guineensis, Piper guineense and Spondias mombin were the most salient. Twenty-two plants are shared by these communities. There is a significant difference concerning wild edible plants shared simultaneously by the three studied communities whereas there is no significant difference about the usage-category. Wild edible plants are used mainly as fruits and vegetables in the studied communities.

Conclusion: The three communities have a high knowledge of wild edible plants. Moreover, fruits and vegetables are the most important usage categories. Finally, the interactions between the three communities bring about the sharing of the knowledge.

Keywords: Alépé, Côte d'Ivoire, Dacryodes klaineana, fruit, Myrianthus arboreus, quantitative ethnobotany, vegetables 


\section{Background}

Throughout the world, each community has developed its own culture which are expressed through the usage of plants (Bédiakon et al. 2018). In order to survive, humans consume plants and animals which contain energy, protein and vitamins (Atungbou 2020). Among those plants, wild edible plants play the main role in many cultures (Coe \& Gaoue 2020). In most African countries, for instance in Benin (Goudégnon et al. 2017), in Uganda (Ojelel et al. 2019) and in Cameroon (Billong Fils et al. 2020), people in rural areas rely basically on wild edible plants for their daily's food.

In Côte d'Ivoire, wild edible plants are associated with exotic plants in the diet of people (Gauthier-Béguin 1992). Before the introduction of exotic species, wild edible plants are parts of traditional culture (Ambé 2001). Unfortunately, the diet of rural people, is gradually changing due to the deforestation and its multiple consequences. For instance, the loss of some plant species, the over-exploitation of natural resources, pollution, and the anthropogenic climate change (Corlett 2016). This situation is becoming worse by the erosion of local wild edible plants and its knowledge (Ojelel et al. 2019). In Côte d'Ivoire the investigations on wild edible plants were based on listing (Kouamé et al. 2008, Nguessan et al. 2015), the nutritional values of local plants (Ehilé et al. 2018), the domestication of wild plants (Bédiakon et al. 2018) and the socio-economic value of wild edible plants (Kouamé et al. 2016), through different regions. These investigations had an intracultural background. Despite these investigations, a little attention is given to sympatric ethnobotanical studies on wild edible plants. We can point out that such studies contribute to the understanding of the reasons why people consume one wild edible plant than other. It also gives the reason of the fall into disuse of a given plant, for instance with changing eating habits (Pardo-de-Santayana et al. 2007). Cognitive salience is an approach which allows the knowledge holders to state the plant name that comes to his/her mind, until they are exhausted in a given domain (Ojelel et al. 2019). This approach assesses the knowledge level of the informants in a given cultural domain. In addition, culture is a shared system of knowledge and competence among a group of people (Tardio \& Pardo de Santayana 2008). The cultural importance of a plant in a given usage category can be defined as the preference of a plant used by the members of a community in a given usage category.

The communities of the study area have been living in close contact for many centuries. The Agni and the Akyé communities belong to the great Akan ethnic group (Kossonou \& Assanvo 2016). Whereas the Gwa communities were adopted in the great Akan ethnic group later on (Goly 2010, Aka 2011). In this context, these communities have the same natural resources. Based on the principle that any usage of a plant is a cultural expression, we assume that the communities of different origins, who live in the same geographical area, could have different food habits. We also assume that their long proximity allows them to share their knowledge in a given domain. This study aimed (i) to assess the diversity of wild edible plants used by the studied communities and knowledge level of the people and (ii) to determine the cultural importance of the usage category of wild edible plants.

\section{Material and Methods \\ Study area}

The study area is located in the Southeastern part of Côte d'Ivoire between $5^{\circ} 13^{\prime} 04.49^{\prime \prime}-5^{\circ} 55^{\prime} 22.06^{\prime \prime} \mathrm{N}$ and $3^{\circ} 25^{\prime} 25.25^{\prime \prime}-3^{\circ} 57^{\prime} 46.64^{\prime \prime} \mathrm{W}$ (Fig. 1). The climate of this area is equatorial and humid, characterized by four alternative seasons (two rainy seasons and two dry seasons). The annual rainfall ranges from 1,200 to 1,600 mm. The annual temperature is $26.4^{\circ} \mathrm{C}$. The vegetation is a Guinean rainforest characterized by Eremospatha macrocarpa (Mann. \& Wendl.) Wendel and Diospyros mannii Hiern (Guillaumet \& Adjanohoun 1971).

The study area harbors three sympatric communities the Agni, the Akye and the Gwa. All of them are unequally spread within five sub-prefectures (Aboisso-Comoé, Alépé, Allosso, Danguira and Oghlwapo). These communities have been settled in their current territory since the beginning of the 18th century. The Agni and the Akyé communities came from the actual Ghana (Diabaté 2013, Adjélou 2016). Whereas the Gwa community came from Liberia (Goly 2010, Aka 2011). At their arrival, these communities were in conflict for their current territory (Bamba et al. 1989). They are essentially farmers. In fact, cultivated plants which represent the main diet are Manihot esculenta Crantz, Musa paradisiaca $\mathrm{L}$ and Colocasia esculenta $(\mathrm{L})$ Schott. These exotic plants are a part of the diet for locals.

\section{Ethnobotanical survey}

Ten (10) villages were surveyed (three villages in the Agni community, four villages in the Akyé community and three villages in the Gwa community). The ten villages were visited in 13 trips from September 2017 to August 2019. The survey was carried out in two steps. 
Step 1. During house-to-house approach, men and women have been interviewed randomly, individually, or collectively. Questions were asked to collect information about the parts of wild edible plants used, their local names, and how there were used (fruit, vegetables, beverages, seasoning). At the end of the interview, we asked for demographic information including matrimonial status and ethnic group of spouses.

Step 2. From the previous list of interviewees, 10 key knowledge holders were selected (three in the Agni community, four in the Akyé and three in the Gwa community), based on the high number of wild edible plants they mentioned. For this step, knowledge holders were interviewed during a walk-in-the wood approach in the surrounding bushes. During these walks, herbarium vouchers of listed plants were collected. Then, the lists collected during the first step added to those collected in the walk-in-the wood was associated. All herbarium vouchers were identified in the laboratory of Botany of NANGUI ABROGOUA University.

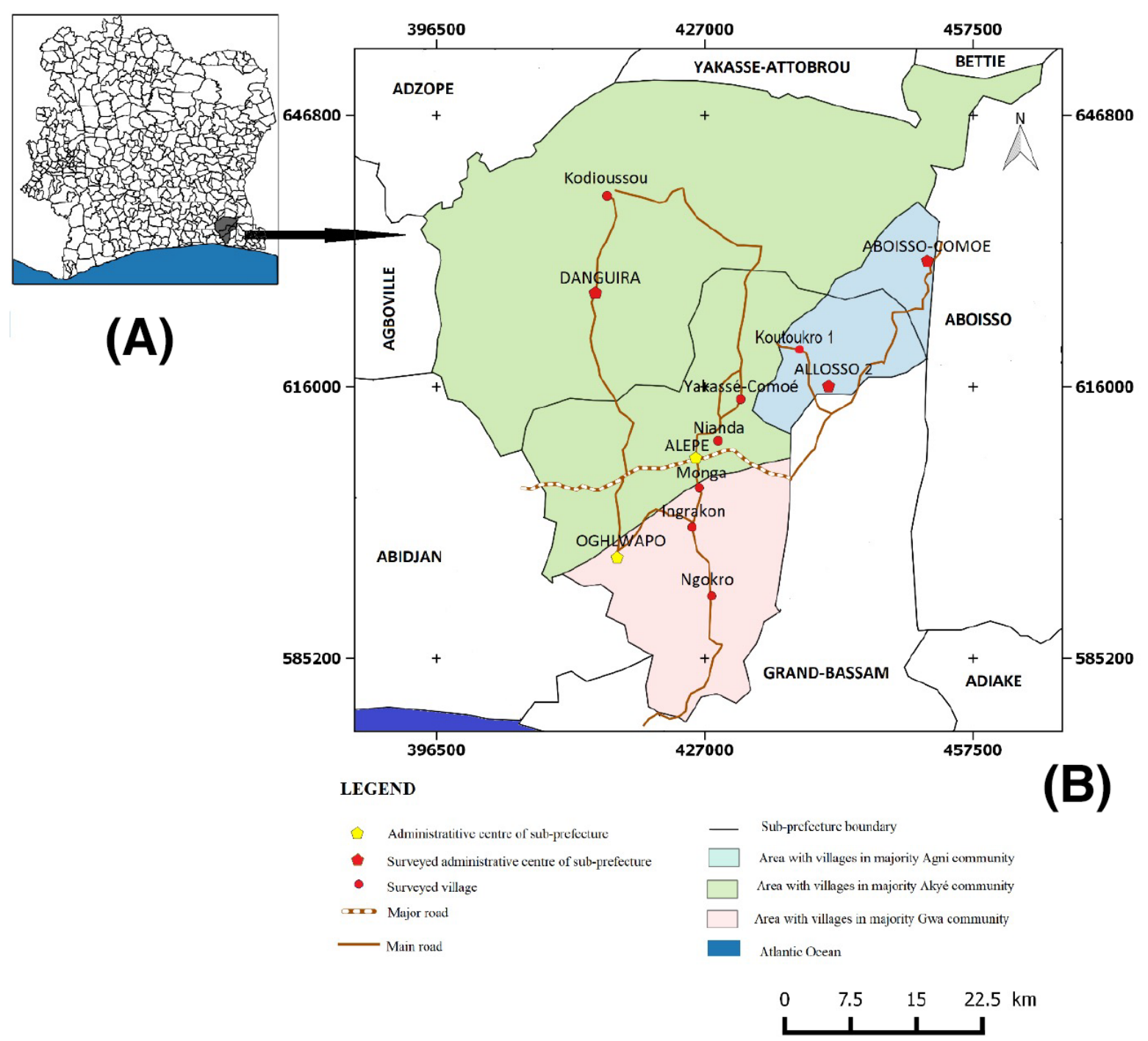

Figure 1. Location of the studied communities: (A) Location of the study area in Côte d'Ivoire; (B) Location of villages sampled in the study area

\section{Data analysis}

Abundance and intercultural relationship of wild edible plants

All knowledge holder's data were grouped per community. The specific richness of wild edible plants exclusive to one community was determined. Then, wild edible plants shared by two communities and simultaneously shared in the three communities, were determined. The result of the survey was obtained with Venn diagram using the VennDiagram package (Chen \& Boutros 2011). Venn diagram shows the overlap of wild edible plants in the studied communities. 
In addition, the Jaccard similarity index (Jaccard 1908), was performed to determine the similarity usage on wild edible plants used by the studied communities. It ranges from $0 \%$ (low similarity) to $100 \%$ (maximum similarity). Knowledge level of wild edible plants

Knowledge level of wild edible plants

In order to obtain the knowledge level of each wild edible plant, the Smith's index (Sutrop 2001, Borgatti 2015), was performed using Anthropac 4.0. It is based on the cognitive salience ( $\mathrm{Sa}$ ) and the frequency of quotation (Fq). The cognitive salience ranges from 0 (low cognitive salience) to 1 (high cognitive salience). Whereas the frequency of quotation ranges from $0 \%$ to $100 \%$. Thus, the cognitive salience and the frequency of quotation are subdivided in three knowledge levels:

$0.32<\mathrm{Sa}<0.72$ and $\mathrm{Fq}>50 \%$ mean that wild edible plants are well known.

$0.11<\mathrm{Sa}<0.33$ and $25 \%<\mathrm{Fq}<50 \%$ means that wild edible plants are moderately known.

$0.001<\mathrm{Sa}<0.12$ and $\mathrm{Fq}<25 \%$ mean that wild edible plants are little known.

Kruskal-Wallis test has used to compare wild edible plants shared by the three communities. This test determines the intercultural convergence about wild edible plants, simultaneously shared by these communities. All statistical analyses were performed with R software (version 4.0.5).

\section{Cultural importance of the usage category}

The cultural importance index $(\mathrm{Cl})$ defined by Tardio \& Pardo-de-Santayana (2008), was assessed in order to determine the spreading of the usage (number of informants) of wild edible plants, but also the diversity of their usages (number of usage categories). The cultural importance of a given plant ranges from 0 (low usage of plants) to 1 (high usage of plants).

In addition, the Mann-Whitney test was used to compare the usage category of wild edible plants between the studied communities.

\section{Distribution of the knowledge}

Hierarchical clustering was performed using different packages (Weller 2005) including FactoMineR to perform the analysis and Factoextra for visualization of the analysis. Hierarchical clustering shows the distribution of wild edible plants through the communities. This hierarchical clustering is based on the preference of each wild edible plant in each community. This preference takes in account the frequency of quotation of each plant.

\section{Results}

\section{Demographic profile of informants}

A total of 445 knowledge holders were surveyed (Table 1). They are distributed among 112 knowledge holders in the Agni community ( 45 men and 67 women), 111 in the Akyé community (52 men and 59 women) and finally 222 knowledge holders in the Gwa community (100 men and 122 women). Of the knowledge holders surveyed, 113 (25.39\%) were between 18 and 39 years. Two hundred and thirty-five (52.81\%) knowledge holders were between 40 and 62 years. Finally, 97 (21.80\%) knowledge holders were between 63 and 87 years.

\section{Abundance and intercultural relationship of wild edible plants}

Forty-three (43) wild edible plants were collected. They are distributed in 39 genera and 25 families of which Malvaceae contained. nine species (18.60\%), Annonaceae, Arecaceae and Phyllanthaceae with three species per family $(6.98 \%)$, are the most represented. $79 \%$ of the species collected are trees and shrubs, $12 \%$ lianas $9 \%$ herbaceous.

A total of 31 wild edible plants were mentioned by the Agni community, 32 plants by the Akyé community and finally 34 wild edible plants were mentioned by the Gwa community. Among these collected plants, 22 (55.16\%) were common to the three communities. Six wild edible plants are exclusively consumed by the Gwa community. In addition, three species are only consumed by the Agni community. Finally, two species are consumed by the Akyé community. Fig. 2 shows the abundance of wild edible plants which are distributed among these communities. Jaccard similarity index is assessed. It ranges from $58.54 \%$ to $70.27 \%$. These values indicate that there is a high similarity between wild edible plants used in the studied communities (Table 2). 
Table 1. Demographic profile of informants $(\mathrm{N}=445)$

\begin{tabular}{|c|c|c|c|c|c|c|}
\hline \multirow[b]{2}{*}{ Ethnic group } & \multicolumn{6}{|c|}{ Age group } \\
\hline & gender & {$[18 ; 39]$} & {$[40 ; 62]$} & {$[63 ; 87]$} & $\begin{array}{c}\text { No. of } \\
\text { informant }\end{array}$ & $\begin{array}{c}\text { No. of } \\
\text { informant } \\
{[n(\%)]}\end{array}$ \\
\hline \multirow{2}{*}{ Agni } & men & 10 & 31 & 4 & 45 & $112(25.17$ \\
\hline & women & 18 & 41 & 8 & 67 & \%) \\
\hline \multirow{2}{*}{ Akyé } & men & 14 & 27 & 11 & 52 & $111(24.94$ \\
\hline & women & 21 & 26 & 12 & 59 & $\%)$ \\
\hline \multirow{3}{*}{ Gwa } & men & 19 & 45 & 36 & 100 & $222(49.89$ \\
\hline & women & 31 & 65 & 26 & 122 & $\%)$ \\
\hline & & $113(25.39 \%)$ & $235(52.81 \%)$ & $97(21.80 \%)$ & 445 & \\
\hline \multicolumn{7}{|c|}{ Matrimonial status } \\
\hline Item & $\begin{array}{l}\text { No. of } \\
\text { informant [n } \\
(\%)]\end{array}$ & Item & $\begin{array}{l}\text { No. of } \\
\text { informant [n } \\
(\%)]\end{array}$ & Item & \multicolumn{2}{|c|}{ No. of informant [n (\%)] } \\
\hline Single Agni & $82(73.21)$ & Single Akyé & 42(37.84) & Single Gwa & \multicolumn{2}{|l|}{ 89(40.09) } \\
\hline $\begin{array}{l}\text { Agni married } \\
\text { to Agni }\end{array}$ & $25(22.32)$ & $\begin{array}{l}\text { Akyé married } \\
\text { to Akyé }\end{array}$ & $59(53.15)$ & $\begin{array}{l}\text { Gwa married } \\
\text { to Gwa }\end{array}$ & \multicolumn{2}{|l|}{$100(45.05)$} \\
\hline $\begin{array}{l}\text { Agni married } \\
\text { to Akyé }\end{array}$ & $4(3.57)$ & $\begin{array}{l}\text { Akyé married } \\
\text { to Agni }\end{array}$ & $8(7.21)$ & $\begin{array}{l}\text { Gwa married } \\
\text { to Akyé }\end{array}$ & \multicolumn{2}{|l|}{$31(13.96)$} \\
\hline $\begin{array}{l}\text { Agni married } \\
\text { to Gwa }\end{array}$ & $1(0.89)$ & $\begin{array}{l}\text { Akyé married } \\
\text { to Gwa }\end{array}$ & $2(1.8)$ & $\begin{array}{l}\text { Gwa married } \\
\text { to Agni }\end{array}$ & \multicolumn{2}{|l|}{$2(0.9)$} \\
\hline
\end{tabular}

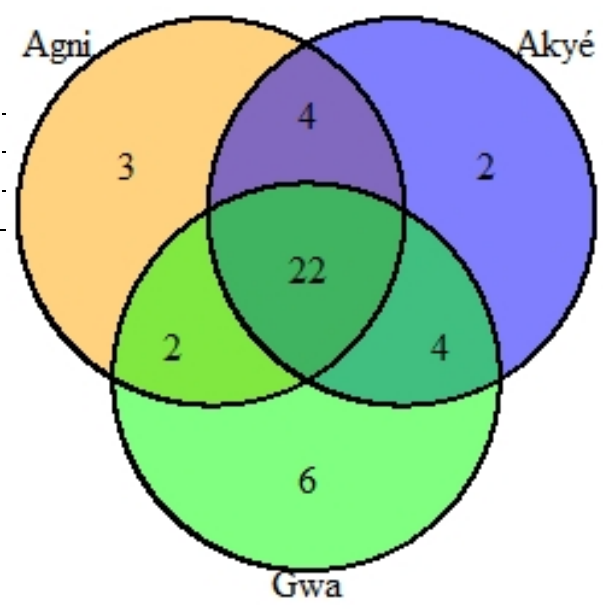

Figure 2. Venn diagram comparing the abundance of wild edible plants used in the studied communities

Knowledge level of wild edible plants in each community

Knowledge levels differ from one community to another. From the 43 wild edible plants, only five (11.63\%), have high cognitive salience and high frequency of quotation values, including Myrianthus arboreus P.Beauv [Akyé (Sa=0.72; $\mathrm{Fq}=89.19 \%)$ ] Fig. 3a, Dacryodes klaineana (Pierre) H.J.Lam [Agni (Sa=0.58; Fq=80.18\%)] Fig. 3b, Elaeis guineensis Jacq [Gwa ( $\mathrm{Sa}=0.54 ; \mathrm{Fq}=87.39 \%) ;$ Akyé ( $\mathrm{Sa}=0.5$; $\mathrm{Fq}=57.66 \%)$, Piper guineense Schumach \& Thonn [Akyé (Sa=0.29; $\mathrm{Fq}=43.24 \%)$ and Spondias mombin L [Agni (Sa=0.33; $\mathrm{Fq}=49.55 \%)]$. Table 3 shows the knowledge level of wild edible plants consumed by the studied communities.

Table 2. Matrix of the similarity of wild edible plants used in the studied communities

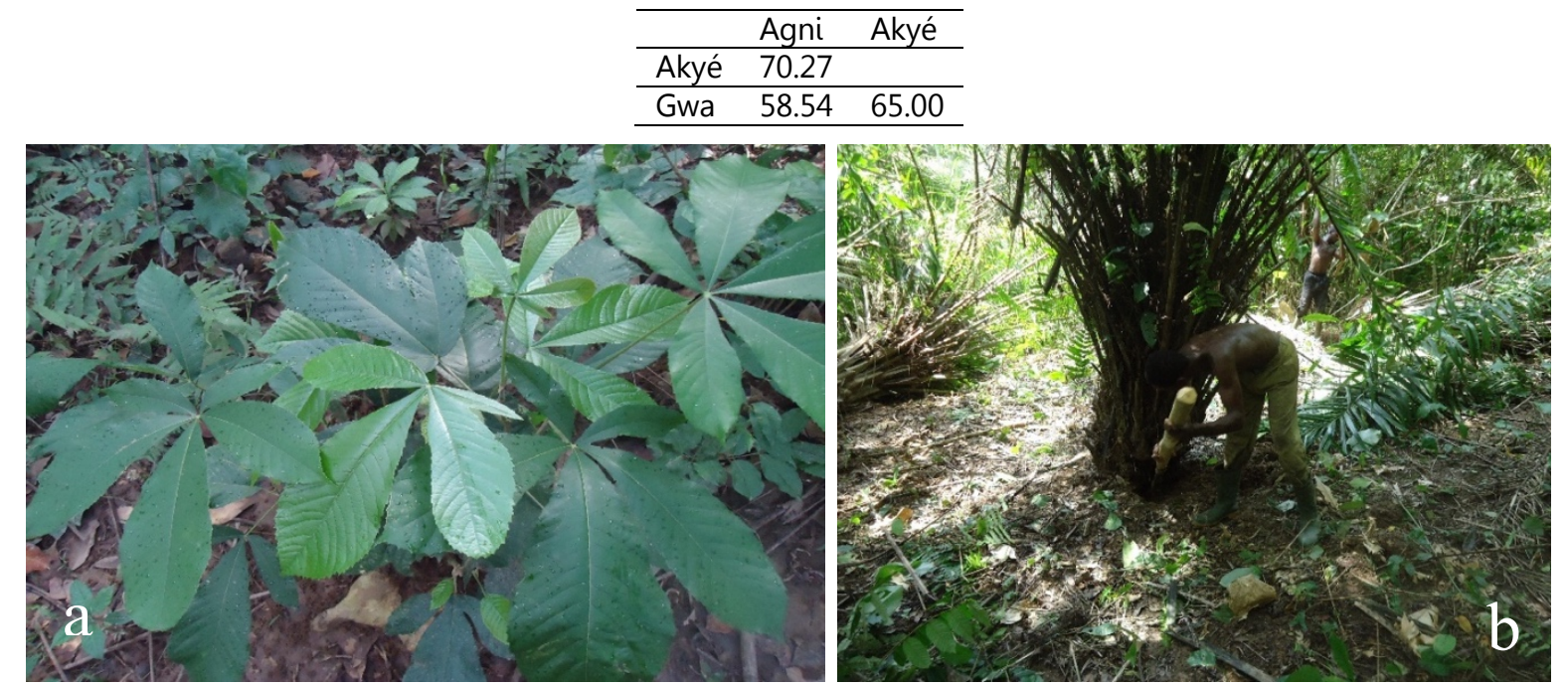

Figure 3. Two wild edible plants with high knowledge level: a) Young leaves of Myrianthus arboreus, b) Cutting down of the tree of Elaeis guineensis for the extraction of the sap as local beverage called 'bandji' 
Ethnobotany Research and Applications

Table 3. Knowledge level of wild edible plants consumed by the studied communities

\begin{tabular}{|c|c|c|c|c|c|c|c|c|c|c|c|c|}
\hline \multirow[t]{2}{*}{ Family } & \multirow[t]{2}{*}{ Species } & \multicolumn{2}{|c|}{ Agni } & \multicolumn{2}{|c|}{ Akyé } & \multicolumn{2}{|c|}{ Gwa } & \multirow[t]{2}{*}{ Part used } & \multirow[t]{2}{*}{ Use } & \multirow{2}{*}{\multicolumn{2}{|c|}{$\begin{array}{l}\text { Akyé } \\
\text { local name }\end{array}$}} & \multirow[t]{2}{*}{ Gwa } \\
\hline & & $\mathrm{Fq}(\%)$ & Sa & $\mathrm{Fq}(\%)$ & Sa & $\mathrm{Fq}(\%)$ & Sa & & & & & \\
\hline \multirow{2}{*}{ Anacardiaceae } & Spondias mombin L. & 49.55 & 0.33 & 18.92 & 0.05 & 29.73 & 0.2 & fruit & raw & troma, & mgba & maga \\
\hline & $\begin{array}{l}\text { Trichoscypha arborea (A. } \\
\text { Chev.) A. Chev. }\end{array}$ & 34.23 & 0.20 & 66.67 & 0.32 & 29.28 & 0.16 & fruit & raw & alèkouli & ndabo & ndrakou \\
\hline \multirow[t]{3}{*}{ Annonaceae } & $\begin{array}{l}\text { Monodora myristica } \\
\text { (Gaertn.) Dunal }\end{array}$ & 14.41 & 0.05 & 3.6 & 0.01 & 7.66 & 0.02 & seed & roasted & èfouan & mkpo & $\operatorname{mmin}$ \\
\hline & $\begin{array}{l}\text { Uvaria afzelii G.F. Scott- } \\
\text { Elliot }\end{array}$ & - & - & - & - & 0.45 & 0.00 & fruit & raw & - & - & doudouglon \\
\hline & $\begin{array}{l}\text { Xylopia aethiopica (Dunal) } \\
\text { A. Rich. }\end{array}$ & - & - & 0.9 & 0.00 & 0.9 & 0.00 & fruit & roasted & essi & foutsan & nuebiho \\
\hline Apocynaceae & $\begin{array}{l}\text { Landolphia hirsuta (Hua) } \\
\text { Pichon }\end{array}$ & 4.5 & 0.04 & - & - & - & - & fruit & raw & amalè & - & - \\
\hline \multirow[t]{2}{*}{ Arecaceae } & Elaeis guineensis Jacq. & 66.67 & 0.44 & 57.66 & 0.50 & 87.39 & 0.54 & $\begin{array}{l}\text { seed, pulp, } \\
\text { fermented } \\
\text { sap }\end{array}$ & $\begin{array}{l}\text { cooked } \\
\text { beverage }\end{array}$ & ayé & tchin & ochi \\
\hline & $\begin{array}{l}\text { Raphia hookeri G. Mann \& } \\
\text { H. Wendl. }\end{array}$ & - & - & 3.6 & 0.01 & - & - & $\begin{array}{l}\text { fermented } \\
\text { sap }\end{array}$ & $\begin{array}{l}\text { raw } \\
\text { beverage }\end{array}$ & - & beunh/banh & - \\
\hline Burseraceae & $\begin{array}{l}\text { Dacryodes klaineana } \\
\text { (Pierre) H.J. Lam }\end{array}$ & 80.18 & 0.58 & 76.58 & 0.44 & 54.95 & 0.43 & fruit & raw & krindja & sè & mgbin \\
\hline Celastraceae & $\begin{array}{l}\text { Salacia nitida (Benth.) N.E. } \\
\text { Br. }\end{array}$ & - & - & - & - & 3.60 & 0.02 & fruit & raw & - & - & nhoué \\
\hline Chrysobalanaceae & Parinari congensis Didr. & - & - & - & - & 3.15 & 0.01 & fruit & raw & - & - & monsè \\
\hline Clusiaceae & Garcinia kola Heckel & 20.72 & 0.1 & 8.11 & 0.04 & 9.91 & 0.07 & seed & raw & tchapiah & tchiouapé & toagbébiho \\
\hline Euphorbiaceae & $\begin{array}{l}\text { Ricinodendron heudelotii } \\
\text { (Baill.) Heckel }\end{array}$ & 19.82 & 0.1 & 24.32 & 0.09 & 14.86 & 0.05 & seed & $\begin{array}{l}\text { cooked } \\
\text { roasted }\end{array}$ & akpi & akpi & bobochi \\
\hline Irvingiaceae & $\begin{array}{l}\text { Irvingia gabonensis (Aubry- } \\
\text { Lecomte ex O'Rorke) Baill. }\end{array}$ & 23.42 & 0.08 & 22.52 & 0.1 & 8.56 & 0.03 & seed & $\begin{array}{l}\text { cooked } \\
\text { roasted }\end{array}$ & kaklou & bé & gbabou \\
\hline Lauraceae & $\begin{array}{l}\text { Beilschmiedia mannii } \\
\text { (Meisn.) Benth. \& Hook. f. } \\
\text { ex B.D.Jacks }\end{array}$ & 0.9 & 0.01 & 19.82 & 0.12 & 5.41 & 0.03 & seed & cooked & bilè & moukouzo & poupouizo \\
\hline Lecythidaceae & $\begin{array}{l}\text { Napoleonaea vogelii Hook. } \\
\text { \& Planch }\end{array}$ & 3.6 & 0.01 & - & - & - & - & fruit & raw & $\begin{array}{l}\text { blémoualou } \\
\text { ah }\end{array}$ & - & - \\
\hline \multirow[t]{5}{*}{ Malvaceae } & Ceiba pentandra (L.) Gaertn. & 18.02 & 0.08 & 30.63 & 0.18 & 11.26 & 0.04 & leave & cooked & ègnan & won & nninyé \\
\hline & $\begin{array}{l}\text { Cola gigantea A. Chev. var. } \\
\text { glabrescens }\end{array}$ & - & - & 21.62 & 0.09 & 24.77 & 0.17 & fruit, leave & $\begin{array}{l}\text { raw } \\
\text { cooked }\end{array}$ & èwalè & awah & tongbaplè \\
\hline & $\begin{array}{l}\text { Cola heterophylla (P. } \\
\text { Beauv.) Schott \& Endl. }\end{array}$ & - & - & - & - & 11.26 & 0.07 & fruit & raw & - & - & okoupo \\
\hline & $\begin{array}{l}\text { Cola nitida (Vent.) Schott \& } \\
\text { Endl. }\end{array}$ & 2.7 & 0.02 & 9.01 & 0.04 & 4.95 & 0.03 & fruit & raw & essorè & leuh & opo \\
\hline & $\begin{array}{l}\text { Glyphaea brevis (Spreng.) } \\
\text { Monach. }\end{array}$ & - & - & 0.9 & 0.01 & - & - & $\begin{array}{l}\text { inflorescenc } \\
\text { e }\end{array}$ & cooked & - & atofin & - \\
\hline
\end{tabular}


Ethnobotany Research and Applications

\begin{tabular}{|c|c|c|c|c|c|c|c|c|c|c|c|c|}
\hline & $\begin{array}{l}\text { Leptonychia pubescens } \\
\text { Keay }\end{array}$ & 10.81 & 0.09 & - & - & - & - & leave & cooked & assotro & - & - \\
\hline & Sterculia tragacantha Lindl. & - & - & 13.51 & 0.08 & 8.56 & 0.04 & leave & cooked & - & mgboto & drèdrèbouè \\
\hline & $\begin{array}{l}\text { Tarrietia utilis (Sprague) } \\
\text { Sprague }\end{array}$ & 25.23 & 0.11 & 16.22 & 0.09 & - & - & leave & cooked & niango & kpanda & - \\
\hline \multirow[t]{2}{*}{ Marantaceae } & $\begin{array}{l}\text { Hypselodelphys violacea } \\
\text { (Ridl.) Milne-Redh. }\end{array}$ & 12.61 & 0.07 & - & - & 2.7 & 0.02 & fruit & raw & $\begin{array}{l}\text { komou- } \\
\text { adjué }\end{array}$ & - & amachi \\
\hline & $\begin{array}{l}\text { Thaumatococcus daniellii } \\
\text { (Benn.) Benth. }\end{array}$ & 7.21 & 0.04 & 2.7 & 0.01 & - & - & fruit & raw & mrouabo- & ndètè & - \\
\hline Melastomataceae & Dicellandra barteri Hook. f. & - & - & - & - & 0.45 & 0.00 & fruit & raw & - & - & ndougo \\
\hline \multirow[t]{2}{*}{ Olacaceae } & Coula edulis Baill. & 50.35 & 0.34 & 37.84 & 0.17 & 4.5 & 0.03 & fruit & $\begin{array}{l}\text { raw } \\
\text { roasted }\end{array}$ & bodjué & atsan & obiablon \\
\hline & Heisteria parvifolia Sm. & 3.6 & 0.00 & - & - & 0.45 & 0.00 & fruit & raw & komou-aliè & - & - \\
\hline \multirow[t]{3}{*}{ Phyllanthaceae } & $\begin{array}{l}\text { Maesobotrya barteri (Baill.) } \\
\text { Hutch. }\end{array}$ & 19.82 & 0.09 & 9.91 & 0.04 & 8.56 & 0.05 & fruit & raw & $\begin{array}{l}\text { kouatié- } \\
\text { koualè }\end{array}$ & abizakouè & gogobin \\
\hline & $\begin{array}{l}\text { Uapaca esculenta A .Chev. } \\
\text { ex Aubrév. \& Leandri }\end{array}$ & 7.21 & 0.04 & 3.6 & 0.02 & 22.97 & 0.14 & fruit & raw & èlèhouba & nanh & ndabinyé \\
\hline & Uapaca heudelotii Baill. & - & - & 0.9 & 0.00 & 0.45 & 0.00 & fruit & raw & - & nombi & odon \\
\hline Piperaceae & $\begin{array}{l}\text { Piper guineense Schumach. } \\
\text { \& Thonn. }\end{array}$ & 24.32 & 0.12 & 43.24 & 0.29 & 21.17 & 0.11 & $\begin{array}{l}\text { leave, fruit, } \\
\text { tige }\end{array}$ & $\begin{array}{l}\text { raw } \\
\text { roasted }\end{array}$ & $\begin{array}{l}\text { assissian- } \\
\text { sian }\end{array}$ & $\begin{array}{l}\text { pako } \\
\text { pakobié } \\
\text { bédi-bédja }\end{array}$ & $\begin{array}{l}\text { gblè } \\
\text { mpouhé } \\
\text { gblègo }\end{array}$ \\
\hline Polygalaceae & Carpolobia lutea G. Don & 9.01 & 0.05 & 8.11 & 0.04 & 11.71 & 0.07 & fruit & raw & sékénouwa & émémou & dodochika \\
\hline Sapindaceae & Blighia sapida K.D. Koenig & 0.9 & 0.00 & 0.9 & 0.00 & - & - & fruit & raw & - & bè & - \\
\hline \multirow[t]{2}{*}{ Sapotaceae } & $\begin{array}{l}\text { Synsepalum brevipes } \\
\text { (Baker) T.D. Penn. }\end{array}$ & - & - & - & - & 8.11 & 0.05 & fruit & raw & - & - & amabiama \\
\hline & $\begin{array}{l}\text { Tieghemella heckelii (A. } \\
\text { Chev.) Pierre ex Dubard }\end{array}$ & 5.41 & 0.02 & 0.9 & 0.00 & - & - & fruit & cooked & doumoré & mgbabou & - \\
\hline \multirow[t]{2}{*}{ Solanaceae } & Solanum indicum $\mathrm{L}$. & 4.5 & 0.03 & 2.7 & 0.02 & 2.25 & 0.01 & fruit & cooked & gnagnan & mangbè & gnagnan \\
\hline & Solanum torvum Sw. & 4.5 & 0.03 & 2.7 & 0.01 & 0.9 & 0.01 & fruit & cooked & kékéissè & kékéyafè & $\begin{array}{l}\text { ablè- } \\
\text { hé/okouhé }\end{array}$ \\
\hline Talinaceae & $\begin{array}{l}\text { Talinum triangulare (Jacq.) } \\
\text { Willd. }\end{array}$ & 6.31 & 0.04 & 18.02 & 0.1 & 56.31 & 0.32 & leave & $\begin{array}{l}\text { cooked } \\
\text { raw }\end{array}$ & $\begin{array}{l}\text { dahomey- } \\
\text { gna }\end{array}$ & achiapa & $\begin{array}{l}\text { ajiamon } \\
\text { ngnangnon }\end{array}$ \\
\hline \multirow[t]{2}{*}{ Urticaceae } & $\begin{array}{l}\text { Musanga cecropioides R. Br. } \\
\text { ex Tedlie }\end{array}$ & 10.81 & 0.08 & 2.7 & 0.01 & 4.5 & 0.02 & leave & cookede & édjui-kokolè & mouin-kaco & $\begin{array}{l}\text { mmoyé- } \\
\text { pépé }\end{array}$ \\
\hline & $\begin{array}{l}\text { Myrianthus arboreus P. } \\
\text { Beauv. }\end{array}$ & 66.67 & 0.37 & 89.19 & 0.72 & 76.58 & 0.46 & leave, fruit & $\begin{array}{l}\text { cooked } \\
\text { raw }\end{array}$ & $\begin{array}{l}\text { niangaman- } \\
\text { tilé }\end{array}$ & $\begin{array}{l}\text { agnan } \\
\text { djinkoudjin }\end{array}$ & $\begin{array}{l}\text { agnronyémi } \\
\mathrm{n}\end{array}$ \\
\hline Zingiberaceae & $\begin{array}{l}\text { Aframomum exscapum } \\
\text { (Sims) Hepper }\end{array}$ & 1.8 & 0.01 & 7.21 & 0.04 & 4.5 & 0.01 & leave & cooked & kablè & miékotéh & moukoulé \\
\hline
\end{tabular}

Fq: frequency of quotation; Sa: cognitive salience; -: species not mentioned by the community 
The Kruskal-Wallis test revealed a significant difference $\left(\mathrm{Khi}^{2}=339.94 ; \mathrm{P}\right.$-value $\left.=2.2 \mathrm{e}^{-16}\right)$, of wild edible plants shared by the three communities. Indeed, the studied communities do not appreciate wild edible plants at the same level.

Parts of wild edible plants used and cultural importance of the usage category

Fruits, leaves, seeds, bark, inflorescence, pulp, and fermented sap are the different parts of wild edible plants consumed. Fruits (55.1\%) and leaves (24.49\%) are mainly the parts used in the study area (Fig. 4).

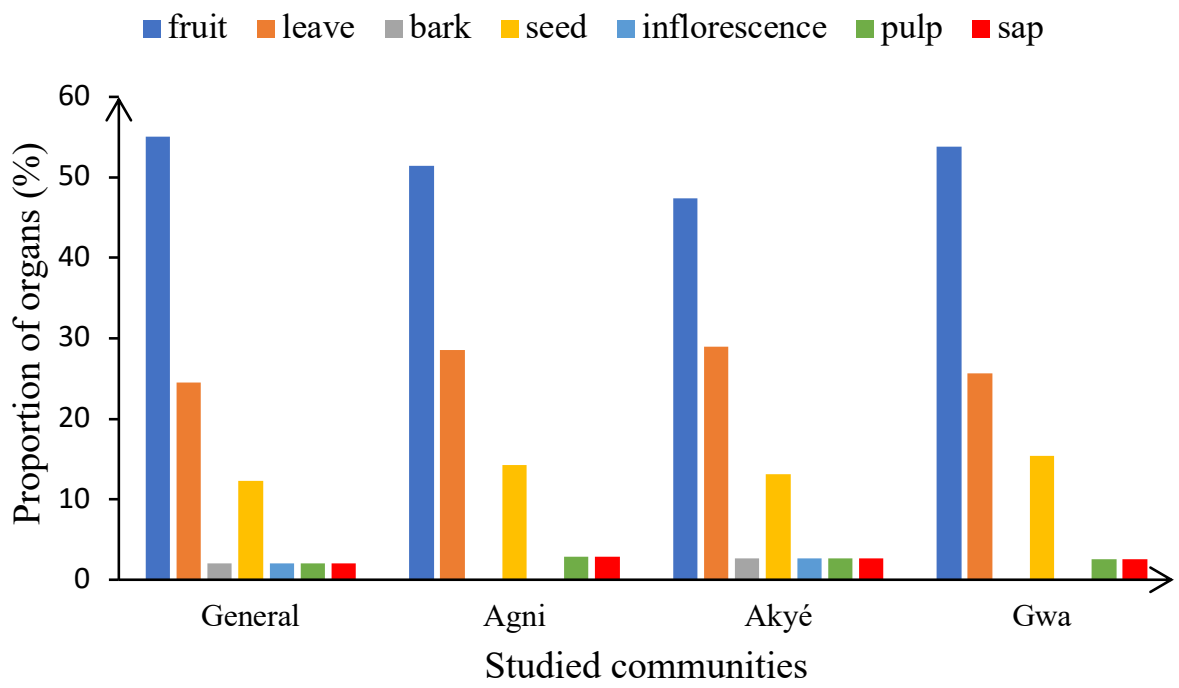

Figure 4. Proportion of wild edible plants used in the studied communities

Concerning the cultural importance of the usage category, the distribution of knowledge is heterogeneous. Indeed, the value of this index changes from one usage category to another. $M$. arboreus $(\mathrm{Cl}=0.77)$ and $D$. klaineana $(\mathrm{Cl}=0.67)$ are culturally significance as fruit. Then, $M$. arboreus $(\mathrm{Cl}=0.77)$ and $E$. guineensis $(\mathrm{Cl}=0.75)$ are significance as vegetables. Finally, E. guineensis $(\mathrm{Cl}=0.76)$ culturally significance as beverage (Table 4).

Table 4. Usage categories and cultural significance of wild edible plants

\begin{tabular}{lll}
\hline Use category & \multicolumn{1}{c}{ species } & IC \\
\hline \multirow{2}{*}{ Fruit } & Myrianthus arboreus P. Beauv. & 0.77 \\
& Dacryodes klaineana (Pierre) H.J. Lam. & 0.67 \\
\hline \multirow{2}{*}{ Vegetables } & Myrianthus arboreus P. Beauv. & 0.77 \\
& Elaeis guineensis Jacq. & 0.75 \\
\hline \multirow{2}{*}{ Beverage } & Elaeis guineensis Jacq. & 0.76 \\
\hline \multirow{2}{*}{ Seasoning } & Piper guineense Schumach. \& Thonn. & 0.27 \\
& Ricinodendron heudelotii (Baill.) Heckel & 0.18 \\
\hline
\end{tabular}

IC: cultural significance index

The Mann-Whitney test revealed that there is no significant difference within the studied communities according to the usage category $(\mathrm{W}=0 ; \mathrm{p}$-value $=1)$. Thus, there is a sharing of knowledge within the studied communities about the usage category. Fig. 5 shows some wild edible plants significant in different usage categories.

The most common usage category is fruit (1470 usage reports) followed by vegetables (1158 usage reports). In contrast, the lowest usage categories are beverages (336 usage reports) and seasoning (231 usage reports). Table 5 shows the usage categories of wild edible plants.

In the study area, all vegetables are served as sauce with various dishes such as rice (Oryza spp.), "foutou" a pounded plantain (Musa paradisiaca) and cassava (Manihot esculenta), or a dish based on fermented cassava called "placali" or "béchiké" or semoulina of cassava "attiéké" or "atoupkou" and brown pounded of cassava called "cocondé". 

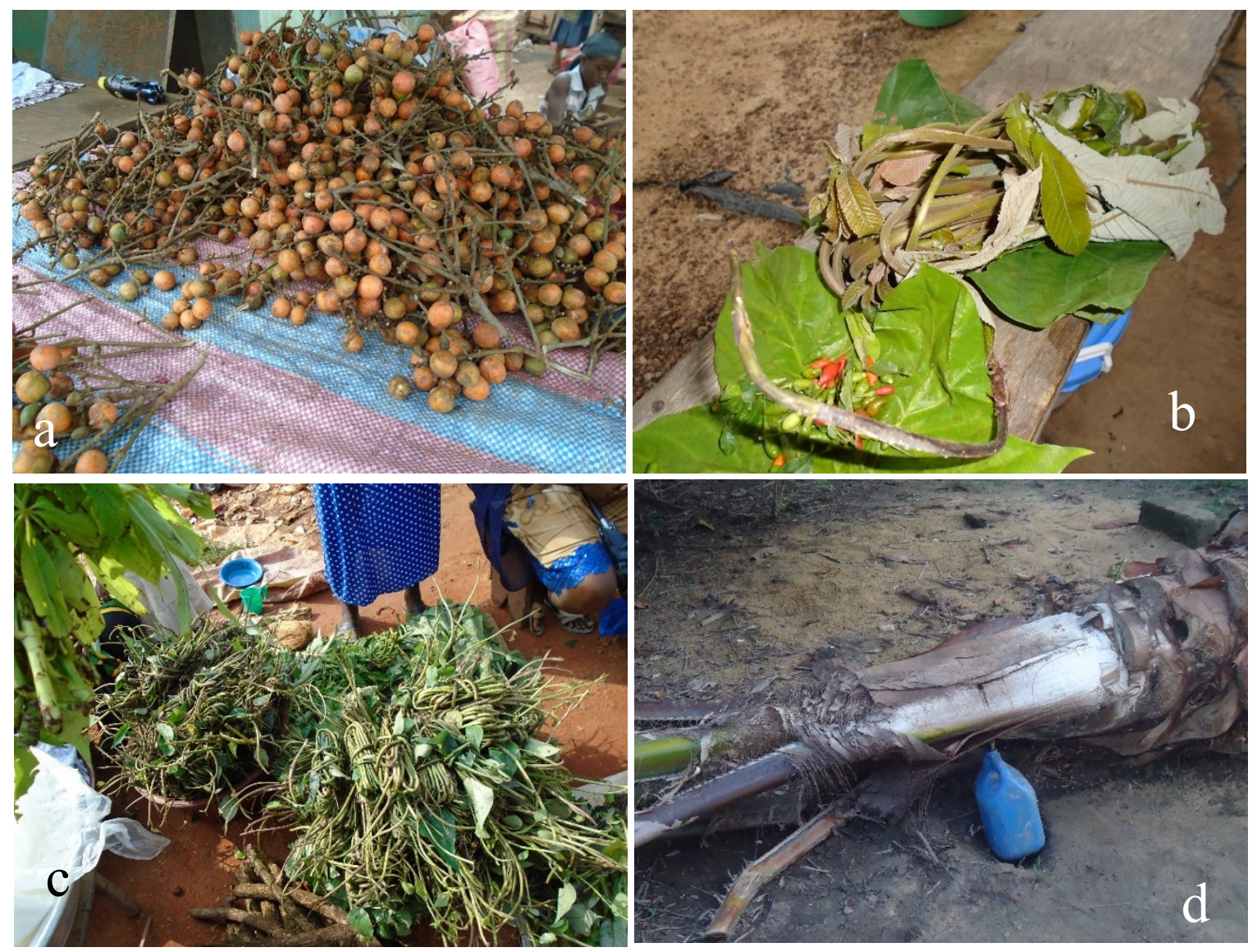

Figure 5. Significance of wild edible plants according to the usages category in the studied communities: a) Fruits of Dacryodes klaineana, b) Buds of Myrianthus arboreus used as vegetables; c) Young lianas of Piper guineense used in seasoning; d) Extraction of the sap of Elaeis guineensis used as beverage

Table 5. Using report of the usage categories of wild edible plants

\begin{tabular}{lc}
\hline Usage category & Number of using report \\
\hline Fruit & 1470 \\
Vegetables & 1158 \\
Beverage & 336 \\
Seasoning & 231 \\
\hline
\end{tabular}

In this study, the same plant obtained different local name. In the Gwa communities $P$. guineense young shoot of the liana is called "gblè". Then the mature liana is known as "gblègo". Finally, the fruit of clusters of the same plant is "mpouhé". While as for the Akyé community, the same $P$. guineense younger shoots of the liana is called "pako". The fruit clusters are "pakobié" and the mature creeper is called "bédi-bédja". That name means "if you ate it, you would marry the cook". Indeed, in African custom, the woman rule is to cook very good meals and to do housework. When that woman makes a delicious sauce with the mature liana of $P$. guineense, she is likely to be taken in marriage by the man who would taste her meal. This is the reason why this plant is called by the Akye community, "bédi-bédja".

\section{Distribution of the knowledge}

The distribution of the knowledge about wild edible plants in the studied communities, gathers them in two groups, according to the preference. The first group (G1) is characterized by wild edible plants mentioned in the Gwa communities. Whereas the second group (G2) is formed by wild edible plants known in the Agni and the Akyé communities (Fig. 6). Thus, the interactions between the studied communities bring about a sharing of their knowledge. 


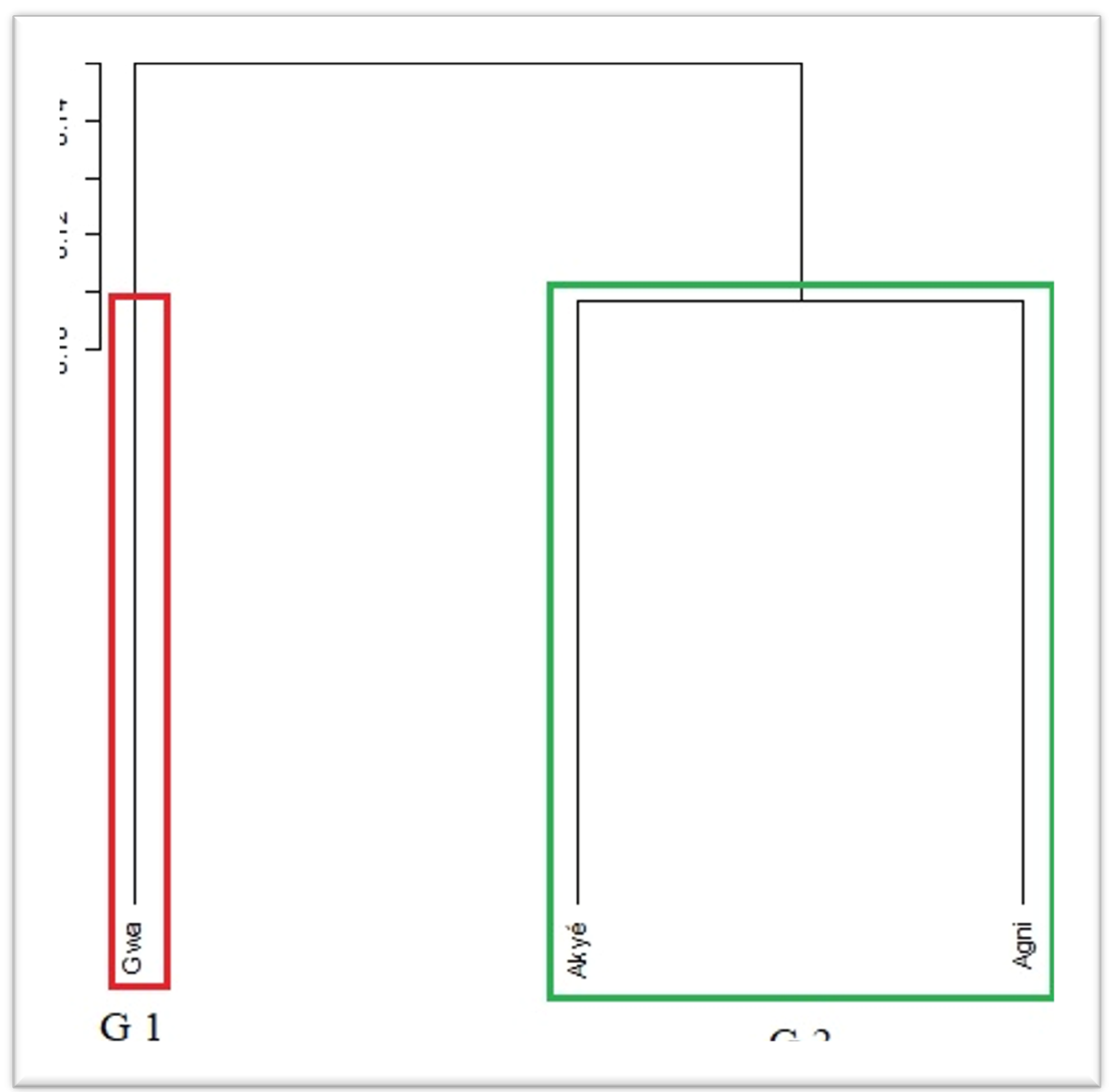

Figure 6. Distribution of the knowledge on wild edible plants used in the studied communities

\section{Discussion}

\section{Diversity of wild edible plants and distribution of knowledge}

From our study, the similarity index showed that the co-presence of wild edible plants mentioned in these communities, is greater than $50 \%$. This result could be explained by the same eating habits of the studied communities. In their studies, Gaoue et al. (2017) indicated that the high similarity on the sharing of knowledge, is due to a long residence of the communities, their interactions as interethnic weddings and the communication through the roads in the same geographical area. Furthermore, Voudouhê et al. (2009) demonstrated in Benin that these high values are widely explained by the interaction of ethnic groups. In fact, these authors indicated that the geographical proximity of communities who live relatively close, share generally many plants. In addition, the high similarity reflects a high interaction within the communities (Amjad et al. 2020). From this point of view, we can conclude that the interaction between communities increases the sharing of knowledge.

From this study, different interactions were recorded. This variation is due to the fact that the studied communities married each other. It has been shown that the preference of a given plant used by a community is influenced by different aspects. Indeed, as demonstrated by Vodouhê et al. (2009) and Salako et al. (2018), the preference depends on the gender and the ethnic group. The variation of wild edible plants would come from the diversity of ethno-species. Indeed, several plants could have the same local name, or several local names could point out the same plants (Ta Bi et al. 2015, Ouattara et al. 2016). These different local names may point out the state of growth of plants or the growth of their fruits or something else. That wild edible plants have a high significance in the local culture as well as in the food domain as in the medicinal domain. Thus, this ethno-species could be one of the key species in the local culture (Coe \& Gaoue 2020).

\section{Knowledge level of wild edible plants}

Plants which have a high knowledge level were D. klaineana, E. guineensis, M. arboreus and $P$. guineense. There are several reasons which could explain the cultural significance of wild edible plants. In fact, the fruits of $D$. klaineana and the fresh young shoots of $M$. arboreus, are sold in quantities in the local market. This great sale is due to the 
sweet taste of fruits, appreciated by communities. In addition, the cultural significance of wild edible plants, in particular D. Klaineana was revealed by Kouamé et al. (2008) and Nguessan et al. (2015), respectively in the Bété community in the central west and in the Krobou community in the southern part of Côte d'lvoire. Moreover, the high knowledge level and the great consumption of the parts used, made wild edible plants important. Thus, $P$. guineense have been used by various organs. The fruits of this plant are used as spices. Its young shoots are used to flavour sauces. Lastly, the bark of the mature liana is scraped and then used to cook a pasty and laxative sauce in the Akyé community. Gnagbo et al. (2017) pointed out that the alcohol mixture with the fruits of $P$. guineense are used as an aperitif in association with the mature creeper of the same plant, cut freshly. In Togo, Atato et al. (2012) demonstrated that the fruits of $P$. guineense are consumed as food and sold in the local market. The high knowledge and the great consumption of the parts of $E$. guineensis give it also a cultural significance. In fact, the pulp of the fruits cooked with water, is used to make a very appreciated sauce in the study area. For instance, in Nigeria the heart of $E$. guineensis tree is used as vegetables (Caliman et al. 2005). In addition, in Nigerian rural communities, people produce a traditional wine from this plant. This traditional wine is highly appreciated as a beverage. It also sold in our study area, as well as other Ivorian communities (Kouakou 2019).

\section{Cultural importance of the usage categories}

The significance of fruits and vegetables could be explained by two reasons. One reason is the means of supply. The studied communities supply easily fruits and vegetables in the vegetation. Similar observations were revealed by Aké et al. (2015). According to these authors, fruits and vegetables are harvested by the people, especially children who appreciate a lot the fruits. The other reason is the availability of organs during the year. According to the studied communities, fruits and vegetables are available during the year and are easily accessible. The investigations of Yao et al. (2015) are confirmed our observations. Indeed, according to these authors in different regions of Côte d'Ivoire, there are different factors that influence the consumption of plants including their availability. The stickiness of leaves guides the studied communities in the choice of vegetables. That is the case of leaves of $M$. arboreus which are sticky and widely consumed as vegetables by communities. This wide consumption of leaves, mainly as vegetables, could be justified by the taste and the ease of cooking. In contrast, according to Atchibri et al. (2012) and Yao et al. (2015) leaves consumed as vegetables do not occupy a prominent place in the eating habits of Ivorians' population. Those observations confirm the low presence of leaves in the diet of the studied communities. In addition, the target communities use the beverage of the sap of E. guineensis, in their eating habits, but also for the economic and socio-cultural value. According to Kouakou (2019), in communities living near the Haut-Sassandra classified forest, the pulp and sap are used respectively in the cooking of sauces and local beverages. However, the beverage usage category obtained a low usage report value in our study. This result could be explained by three different reasons. First, a high effort is required to cut down a palm tree. After cutting down of palm trees, there is a daily cutting of the apical bud to maintain the flow of sap. Finally, the daily gathering and heating of the apical bud to facilitate the flow of the sap, are exhausting for the collector. These different steps and techniques make that few people are interested by this practice. Kouchade et al. (2017) in Benin revealed similar observations. According to these authors, the Beninese communities extract the sap of $E$. guineensis, from various steps and techniques which are very exhausting. However, few wild edible plants are used in seasoning by the studied communities. This result could be explained by the fact that the seasoning based on plants becomes obsolete in the eating habits of these communities. Indeed, communities substitute meal seasoning plants with stock cubes. Mananga et al. (2020) in Congo showed that the Komono communities consume Tiliacora funifera (Miers) Oliv, leaves as a spice well as seasoning. In fact, according to these authors that plant is very well known and enhances the taste of the dish by making it tender and appetising during consumption. This difference in results could be explained by the disuse of traditional seasoning plants. However, the usage categories contain the most versatile and well-known wild edible plants with no significant difference between communities. This result could be explained by the usage of wild edible plants in the same way. In sudanian zone of Benin, there was a significant difference between 11 communities, concerning food and medicine, the usage categories of Lannea microcarpa Engl. \& K.Krause. For Goudégnon et al. (2017) indicated that this plant was more significance as food for the Otamari, the Dendi and the Natimba communities. In reverse, the same plant, has been ranked by the Biali, the Waama, the Mokolé, the Dendi and the Natimba communities as medicine. This difference could be explained by the different cultural context, but also by the different origins of the communities. The fruits may be consumed alone, raw or roasted. As for the leaves, there are used as vegetables. Therefore, there are cooked and consumed with a food rich in starch. These wild plants are consumed so much in our study. Thus, there contribute greatly in helping rural communities to reach their food security. According to Gauthier-Béguin (1992) in West Africa, rural communities which are living in rainforest areas benefit from a balanced diet, with a very high intake of vitamins, proteins and carbohydrate from the harvest of wild edible plants. In the same way, Acho et al. (2014), revealed that wild edible plants remain significance in the diet of the rural communities. 


\section{Conclusion}

This study showed the differences and the similarities between the studied communities, on 43 wild edible plants. These communities have a good knowledge of wild edible plants. They use it as fruits and vegetables. Finally, the interactions as weddings led to the sharing of knowledge between the studied communities.

\section{Declarations}

Ethics approval and consent to participate: Before starting study, the chief of each investigated village was informed on the study project. Then, an agreement was needed to residents prior to start questions. Local inhabitants of the study area gratefully acknowledged for sharing valuable information.

Availability of data and materials: Data are available from the first author.

Competing interests: The authors declare that they have no competing interest.

Funding: This study did not receive any specific grant from funding agencies.

Author contributions: AL Diop led the field data collection and has performed the data analysis. AL Diop and DF Malan designed the subject and the methodological approach. For the writing DF Malan, YB Kouakou, AL Litta and KG Kouassi, critically revised this manuscript. All authors read and approved it as the final manuscript.

\section{Literature cited}

Acho CF, Zoué LT, Akpa EE, Yapo VG, Niamké SL. 2014. Leafy vegetables consumed in southern Côte d'Ivoire: a source of high value nutrients. Journal of Animal and Plant Sciences 3:3159-3170.

Adjélou JB. 2016. Société traditionnelle et économie monétaire en pays Akyé de 1875 à 1946 . Thèse de doctorat, Université d'Abidjan.

Aka K. 2011. Traditions musicales chez les Akans lagunaires de Côte d'Ivoire: cas des Abbey, Abidji, Ehotilé et M'batto. Tervuren, Belgium: Musée royal de l'Afrique centrale.

Aké CB, Nguessan K, Kouamé NMT. 2015. Traditional consumption stateous of wild food and mushrooms species in Abidjan and Agboville (Côte d'Ivoire). European Journal Scientific Research 135: 182-195.

Ambé GA. 2001. Les fruits sauvages comestibles des savanes guinéennes de Côte d'Ivoire: état de la connaissance par une population locale, les Malinké. Biotechnologie Agronomie Société et Environnement 5:43-58.

Amjad MS, Zahoor U, Bussmann RW, Altaf M, Gardazi SMH, Abbasi. 2020. Ethnobotanical survey of the medicinal flora of Harighal, Azad Jammu \& Kashmir, Pakistan. Journal of Ethnobiology and Ethnomedicine 16:65.

Atato A, Wala K, Dourma M, Bellefontaine R, Woegan YA, Batawila K, Akpagana K. 2012. Espèces lianescentes à fruits comestibles du Togo. Fruits 67:353-368.

Atchibri OAAL, Soro LC, Kouamé C, Agbo EA, Kouadio KKA. 2012. Valeur nutritionnelle des légumes consommés en Côte d'Ivoire. International Journal of Biological and Chemical Sciences, 6(1):128-135.

Atungbou N. 2020. Food practice for physical and spiritual well-being of the Zeme, the tribe in Northeast India. Journal of Ethnic Foods 7:41.

Bamba S, Gonnin G, Kodjo GN, Nagnin O, Ouattara FT, Tiacoh C, Yao K, Zunon JG. 1989. Mémorial de la Côte d'Ivoire.

Bédiakon BKD, Beugré GAM, Konan Y, Ouattara D. 2018. Enquête ethnobotanique sur les plantes spontanées alimentaires dans le département d'Agboville (Côte d'Ivoire). International Journal of Scientific and Engineering Research 9:1843-1856.

Billon Fils PE, Nana NA, Betti JL, Njimbam OF, Womeni ST, Martin EA, Brull GR, Okale R, Fa JE, Funk. 2020. Ethnobotanical survey of wild edible plants used by Baka people in southeastern Cameroon. Journal of Ethnobiology and Ethnomedicine 16:64.

Borgatti SP. 2015. Software Review. Fields Method 27:199-205.

Caliman JP, Berthaud A, Dubois B, Tailliez B. 2005. Agronomy, sustainability and good agricultural practices. OCLOléagineux, Corps gras, Lipides 1:134-140.

Chen H \& Boutros PC. 2011. VennDiagram: a package for the generation of highly-customizable Venn and Euler diagrams in R. BMC Bioinformatics 12:35.

Coe MA \& Gaoue OG. 2020. Cultural keystone species revisited: are we asking the right questions? Journal of Ethnobiology and Ethnomedicine 16:70.

Corlett RT. 2016. Plant diversity in a changing world: status, trends, and conservation needs. Plant Diversity 38(1):1016. 
Diabaté DH. 2013. La formation des sanvi dans le sanvi, un royaume Akan (1701-1901). Luballery, France.

Ehilé ESJ, Kouassi NK, Kouamé CA, Ndri DY, Amani NG. 2018. Nutritional composition of five spontaneous wild plants used as human foods in Côte d'Ivoire areas (West Africa) a potential role in household food security. Pakistan Journal of Nutrition 17:171-178.

Gaoue OG, Coe MA, Bond M, Hart G, Seyler BC, McMillen H. 2017. Theories and major hypotheses in Ethnobotany. Economic Botany 71:269-287.

Gauthier-Béguin D. 1992. Etude ethnobotanique des plantes de cueillette à utilisation alimentaire dans un village du Sud du V-Baoulé. Côte d'Ivoire centrale. Thèse de doctorat, Université de Genève.

Gnagbo A, Koffi KAD, Koffi AB, Kouamé D, Goné Bi ZB, Adou Yao CY. 2017. Valeurs d'usage et importance socioéconomique de Piper guineense Schumach. \& Thonn. (Piperaceae) chez les populations riveraines du Parc national d'Azagny (Sud Côte d'Ivoire). Revue de l'environnement et de la Biodiversité-PASRES 2:31-41.

Goly AM. 2010. Culture Ghwa: Histoire et Tradition. Abidjan, Graphic Excel.

Goudégnon EOA, Vodouhê FG, Gouwakinnou GN, Salako VK, Oumorou M. 2017. Ethnic and generational differences in traditional knowledge and cultural importance of Lannea microcarpa Engl. \& K. Krause in Benin's Sudanian savanna. Bois et Forêts des Tropiques 334:49-59.

Guillaumet JL, Adjanohoun E. Végétation de la Côte d'Ivoire. 1971. In: Avenard JM, Eldin M, Girard G, Sircoulon J, Touchebeu P, Perraud A, editors. Le milieu naturel de Côte d'Ivoire. Mémoires ORSTOM.

Jaccard P. Nouvelles recherches sur la distribution florale. 1908. Bulletin de la Société Vaudoise des Sciences Naturelles 44:223-270.

Kossonou KT \& Assanvo AD. 2016. Linguistique et migration des peuples en Côte d'Ivoire: cas des Akans (Kwa). Revue du CAMES: Littérature, langues et linguistique 4:106-119.

Kouakou KA. 2019. Disponibilité et vulnérabilité des espèces sources de produits forestiers non ligneux d'origine végétale de la forêt du Haut-Sassandra et sa périphérie après la décennie de crise au Centre-Ouest de la Côte d'Ivoire. Thèse de doctorat, Université Daloa.

Kouamé NMT, Aké CB, Mangara A, Nguessan K. 2016. Analyse de l'intérêt socio-économique des graines de Garcinia kola Heckel (Clusiaceae) dans la commune de Koumassi (Abidjan), Côte d'Ivoire. International Journal of Biological and Chemical Sciences 10:2587-2595.

Kouamé NMT, Gnahoua GM, Kouassi KE, Traoré D. 2008. Plantes alimentaires spontanées de la région du fromager (Centre-Ouest de la Côte d'Ivoire): flore, habitats et organes consommés. Sciences et Nature 5:61-70.

Kouchadé AC, Kounouheva B, Awokou KS. 2017. La récolte du vin de palme: procédé et effets des conditions environnementales. Oilseeds \& fats Crops and Lipids, 24(5).

Mananga V, Itoua Okouango YS, Moukassa W, Boukou GJ, Elenga M. 2020. Évaluation de la consommation et caractérisation nutritionnelle des feuilles de Tiliacora funifera. Journal of Applied Biosciences, 154:15888-15904.

Nguessan K, Kouamé NMT, Assi-Kaudjhis C, Aké CB. 2015. Ethnobotanical study of spontaneous wild plants used for food by Krobou people, in the south of Côte d'Ivoire. Journal of Global Biosciences 4:1354-1365.

Ojelel S, Mucunguzi P, Katuura E, Kakudidi EK, Namaganda M, Kalema J. 2019. Wild edible plants used by communities in and around selected forest reserves of Teso-Karamoja region, Uganda. Journal of Ethnobiology and Ethnomedicine 15:3.

Ouattara ND. 2016. Diversité floristique et ethnobotanique des plantes sauvages comestibles dans le Département de Bondoukou (Nord-Est de la Côte d'Ivoire). Journal of Applied Biosciences 98:9284-9300.

Pardo-de-Santayana M, Tardo J, Blanco E, Carvalho AM, Lastra JJ, San Miguel E, Morales R. 2007. Traditional knowledge of wild edible plants used in the northwest of the Iberian Peninsula (Spain and Portugal): a comparative study. Journal of Ethnobiology and Ethnomedicine 3:27.

Salako KV, Moreira F, Gbedomon RC, Tovissodé, Assogbadjo AE, Kakaî RLG. 2018. Traditional knowledge and cultural importance of Borassus aethiopum Mart. in Benin: interacting effects of socio-demographic attributes and multi-scale abundance. Journal of Ethnobiology and Ethnomedicine 14:36.

Sutrop U. 2001. List task and a cognitive salience index. Field methods 13:263-276.

Ta Bi IH, Nguessan K, Bomisso EL, Assa RR, Aké S. 2016. Etude ethnobotanique de quelques espèces du genre Corchorus rencontrées en Côte d'Ivoire. European Scientific Journal 12:415-431.

Tardio J, Pardo-de-Santayana M. 2008. Cultural importance indices: a comparative analysis based on the useful wild plants of southern Cantabria. Economic Botany 62:24-39. 
Vodouhê FG, Coulibaly O, Greene C, Sinsin B. 2009. Estimating the local value of non-timber forest products to Pendjari biosphere reserve dwellers in Benin. Economic Botany 63:397-412.

Weller SC. 2005. Correspondence Analysis. Encyclopedia of Biostatistics.

Yao K, Koné MW, Kamanzi K. 2015. Contribution des légumes feuilles à la nutrition des populations en zones urbaines de la Côte d'Ivoire. European Journal of Scientific Research 130:338-351. 